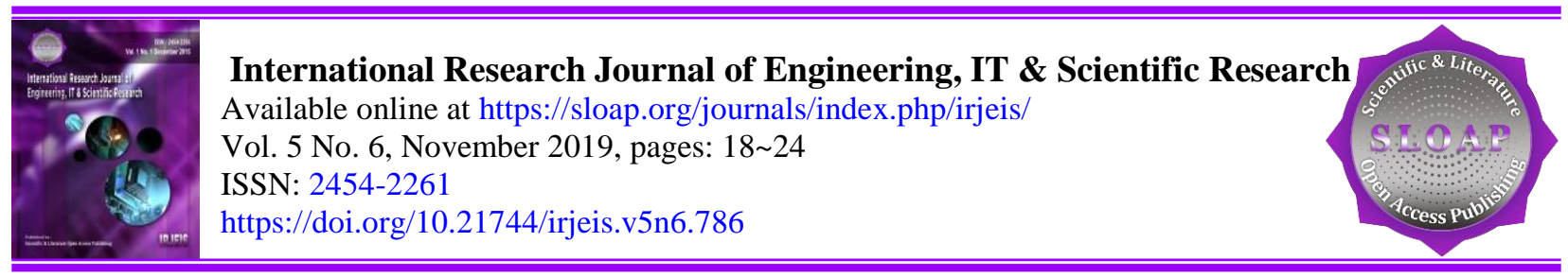

\title{
Radiation Protection X-Ray in the Diagnostic Radiology Unit Kasih Ibu Kedonganan Hospital
}

\author{
I Ketut Putra ${ }^{a}$ \\ Ida Bagus Made Suryatika ${ }^{\text {b }}$ \\ I Gusti Agung Ayu Ratnawati ${ }^{c}$ \\ Gusti Ngurah Sutapa ${ }^{d}$
}

Article history:

Received: 27 February 2019

Accepted: 30 September 2019

Published: 31 October 2019

Keywords:

$D L V$;

exposure test;

radiation protection;

radiology;

$X$-ray;

\begin{abstract}
One source of radiation is X-ray aircraft, which utilization must pay attention to safety aspects. Room design is the first step that must be done before the operation of X-ray aircraft. Radiology Unit Kasih Ibu Kedonganan Hospital operates an X-ray aircraft with specifications of $250 \mathrm{kV}-85 \mathrm{~mA}$, needs to be tested for radiation exposure which is an integral part of the verification of radiation protection. Test for radiation exposure at least once a year. The purpose of the installation room design is to ensure that workers or the general public around the plant receive radiation exposure that is smaller than the applicable dose limit value (DLV), by the radiation safety provisions that refer to the Decree. BAPETEN No. 7 of 2009 concerning Radiation Safety in the use of radiographic equipment. This study will test exposure to room wall shields associated with radiation workers and the general public. The results showed that all walls A, B, C, D, and E could still completely weaken the rate of $\mathrm{X}$-ray radiation. The highest radiation dose detected on wall $\mathrm{B}$ is the primary wall for the Buky stand examination. The value of wall $\mathrm{B}$ dose reaches $0.044 \mathrm{mR}$ or $0.44 \mu \mathrm{Sv}$ in a year. So that the radiation dose outside the wall is still below the DLV which is $5 \mathrm{mSv}$ for radiation workers and $50 \mathrm{mSv}$ for the general public. Thus the radiation protection in the Radiology unit Kasih Ibu Kedonganan Hospital is verified as safe for workers and the general public.
\end{abstract}

2454-2261 ${ }^{\circledR}$ Copyright 2019. The Author. This is an open-access article under the CC BY-SA license (https://creativecommons.org/licenses/by-sa/4.0/) All rights reserved.

\footnotetext{
Author correspondence:

I Ketut Putra,

Faculty of Physics, Mathematics and Natural Sciences, Udayana University,

Bukit Jimbaran Badung, Indonesia.

Email address: putra_jongrang@rocketmail.com
}

\footnotetext{
${ }^{a}$ Udayana University, Denpasar, Indonesia

${ }^{\mathrm{b}}$ Udayana University, Denpasar, Indonesia

${ }^{\mathrm{c}}$ Udayana University, Denpasar, Indonesia

${ }^{\mathrm{d}}$ Udayana University, Denpasar, Indonesia
} 


\section{Introduction}

The use of radiation technology in addition to the benefits for human welfare can also be found in technical aspects that have a potential danger to human safety. Therefore, standard safety guidelines that contain basic requirements to protect humans and the environment against radiation hazards must be obeyed. One application of radiation for peaceful purposes is its use in the field of medicine, especially the radiology unit. This application has been quite diverse, ranging from radiation for diagnostic purposes, X-ray examination of teeth, the use of radiopharmaceuticals, to irradiation for therapeutic purposes.

One source of radiation is X-ray aircraft. X-rays have the potential for radiation hazards, so their use must pay attention to aspects of radiation protection. Also, X-ray aircraft must be in good condition and maintained according to a quality assurance program. X-ray aircraft by the factory are equipped with radiation shields which also function as tube housings (Akhadi, 2000). Nevertheless, the possibility of radiation leakage still needs to be taken into account. In the case of a single radiation cover attached, leakage can occur through the gap of the X-ray tube cover or a gap that occurs by changing the shape of the cover (Bushong, 1993). From the foregoing, the design of an installation room that meets safety standards is the first step that must be met, before the operation of an X-ray aircraft. The purpose of the design of the installation room is to ensure that workers or the general public around the plant receive less radiation exposure from the applicable dose limit value.

Radiation safety provisions that refer to BAPETEN No. 7 of 2009 concerning Radiation Safety in the use of industrial radiography equipment states that (Fakhri \& Wildan, 2015):

1) Room wall shields associated with community members, the Dose Limit Value must not exceed $5 \mathrm{mSv}$ per year.

2) Room wall shields associated with radiation workers, the Dose Limit Value may not exceed $50 \mathrm{mSv}$ per year.

Room wall characteristics must be adjusted to the use of a room that borders the radio diagnostic room. The thickness of the concrete wall can be determined by calculating the weekly workload, the distance of the source to the wall and the allowable the Dose Limit Value (Cember, 1992). From the verification of the radiation protection calculation results are expected to still meet the radiation safety requirements.

\section{Materials and Methods}

The location of the study was at the Radiology Unit of Kasih Ibu Kedonganan Hospital. Research using X-ray aircraft and dose rate measurement with a radiation survey meter. Measurements were made on primary and secondary walls for on bed and bucky stand examinations with observed variables including exposure, source distance, exposure rate, user factors, unit factors, and aircraft workload. Exposure test measurements are carried out on the walls as shown in Figure 1 below.

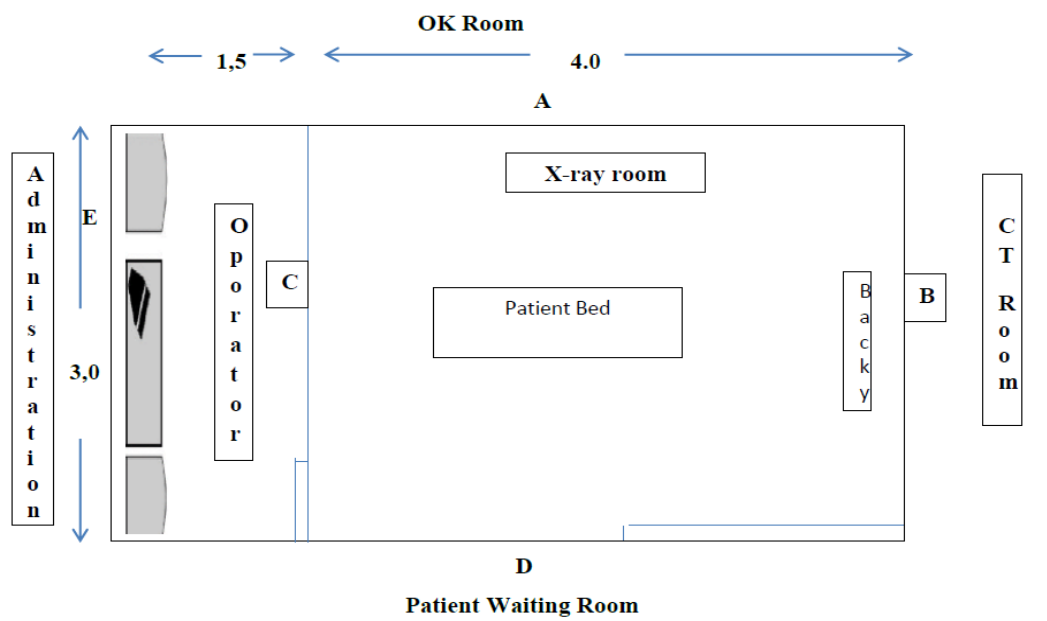

Figure 1. Primary and secondary wall position at the radiological unit room

Putra, I. K., Suryatika, I. B. M., Ratnawati, I. G. A. A., \& Sutapa, G. N. (2019). Radiation protection x-ray in the diagnostic radiology unit kasih ibu kedonganan hospital. International Research Journal of Engineering, IT \& Scientific Research, 5(6), 18-24. https://doi.org/10.21744/irjeis.v5n6.786 
The process of measuring the area of an X-ray aircraft room and the distance of an X-ray source to the wall of the room by using a meter and the thickness of the shield wall on each side of the room by using a caliper and recording the measurement results. The measurement of the dose rate is carried out in the position of the irradiation direction with PA (Postero Anterior) projection using the exposition factor of 50,70 and $100 \mathrm{kV}$, and a tube current of $85 \mathrm{~mA}$. Radiation dose rate measurements were carried out as many as 5 times the measurements and measurements were carried out for each primary room wall (A, C, D, and E) and secondary (B). Data from the measurement of exposure, source distance, exposure rate, user factors, unit factors, and aircraft workload were analyzed by independent $\mathrm{T}$ statistic test comparing T-count with T-table at $\alpha=0.05$.

\section{Results and Discussions}

The results of measurements made on the primary and secondary walls as shown in Figure 1 above for the type of on bed inspection at $85 \mathrm{~mA}$ with PA projections are shown in Table 1. And are represented in the graph as in Figure 2 below,

Table 1

Dosage Rate in On Bed Examination with PA Projection

\begin{tabular}{llll}
\hline \multirow{2}{*}{ Wall } & \multicolumn{3}{c}{ Dosage Rate $(\mu \mathrm{Sv})$} \\
\cline { 2 - 4 } & $50 \mathrm{kV}$ & $70 \mathrm{kV}$ & $100 \mathrm{kV}$ \\
\hline $\mathrm{A}$ & 0,0027 & 0,0074 & 0,0114 \\
$\mathrm{~B}$ & 0,009 & 0,0102 & 0,0102 \\
$\mathrm{C}$ & 0,012 & 0,0132 & 0,0199 \\
$\mathrm{D}$ & 0,0034 & 0,008 & 0,0103 \\
$\mathrm{E}$ & 0,0004 & 0,0074 & 0,0081 \\
\hline
\end{tabular}

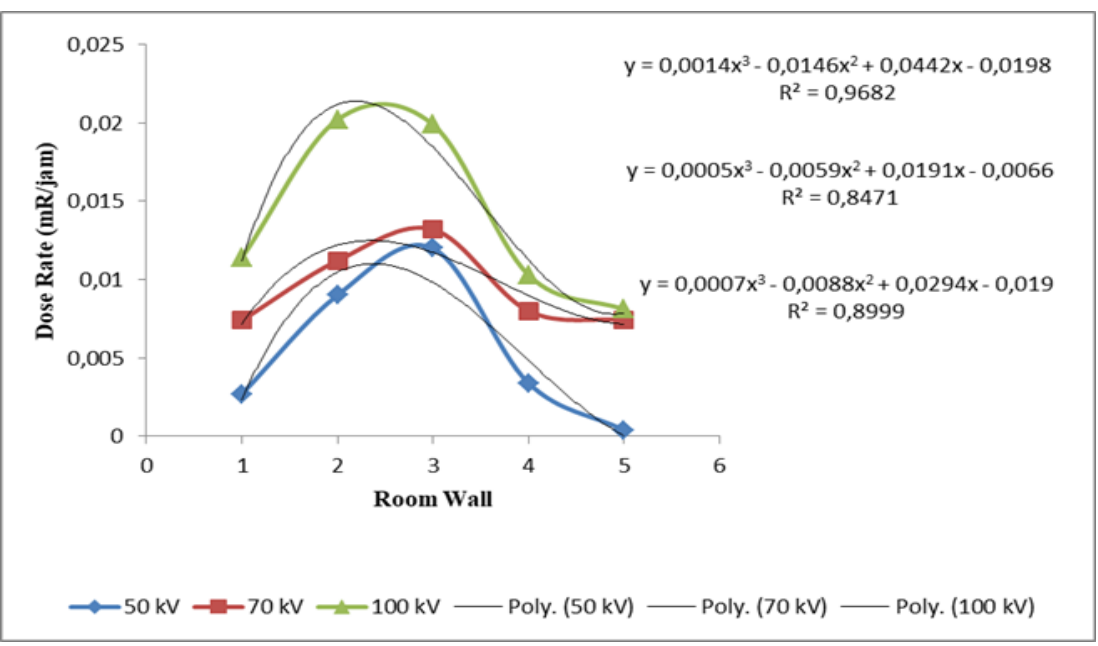

Figure 1. Radiation dosage rate at the secondary wall for examination on bed

The dose rate at the on bed examination for all walls (A, B, C, D, and E) is a secondary wall. Whereas the primary wall in the on bed inspection condition occurs on the floor of the room. Figure 1 shows that the dose rate has the same trending trend pattern for the $\mathrm{X}$-ray tube voltage of 50,70 and $100 \mathrm{kV}$. However, with greater $\mathrm{kV}$, the dose rate detected outside the secondary wall is greater. This shows that increasing the $\mathrm{kV}$ will cause the ability to penetrate $\mathrm{X}$-ray radiation even further. Wall $\mathrm{C}$ receives the highest radiation dose compared to other walls. Wall $\mathrm{C}$ is the nearest wall which is about $1 \mathrm{~m}$ from the source of X-ray radiation at the inspection position on the bed and wall $\mathrm{E}$ is the wall that receives the lowest radiation dose. This condition is in accordance with the radiation protection theory proposed by Muklis Ahkadi (2000), where the fastest way to reduce the radiation dose is to stay away from the source of the radiation (Fakhri \& Wildan, 2015). It is also in accordance with the principle of radiation safety distance regulation where the radiation dose rate will be inversely proportional to the square of the distance, so the 
greater the radiation range to a measurement point, the measured dose rate will be lower (Wulandhari et al., 2015; Sutapa et al., 2018).

The type of bucky stand examination shows a different dosage rate from the examination on the type of on bed examination. Measurement data can be shown in Table 2 and plotted into the graph as shown in Figure 3 below,

Table 2

Dosage Rate in Bucky Stand Examination with PA Projection

\begin{tabular}{cccc}
\hline \multirow{2}{*}{ Wall } & \multicolumn{3}{c}{ Dosage Rate $(\mu \mathrm{Sv})$} \\
\cline { 2 - 4 } & $50 \mathrm{kV}$ & $70 \mathrm{kV}$ & $100 \mathrm{kV}$ \\
\hline A & 0,003 & 0,007 & 0,013 \\
B & 0,029 & 0,039 & 0,044 \\
C & 0,0007 & 0,0013 & 0,002 \\
D & 0,0034 & 0,0071 & 0,0094 \\
E & 0,002 & 0,0005 & 0,002 \\
\hline
\end{tabular}

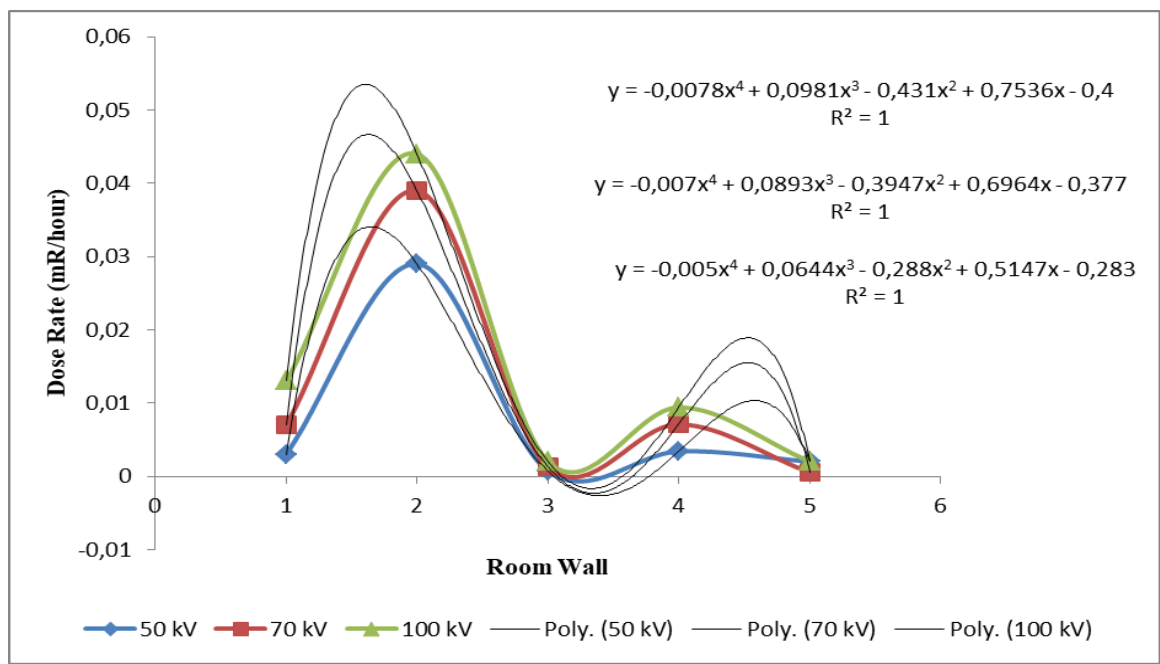

Figure 3. Radiation dosage rate in primary and secondary walls for bucky stand examination

Wall B as shown in Figure 3 receives the highest dose rate compared to walls A, C, D, and E, this is because wall B is the primary wall at the time of the bucky stand inspection. Very low dose rates occur in walls A, C, D, and E, because these walls are secondary walls. The dose rate received from each wall is highly dependent on the $\mathrm{kV}$ of the $\mathrm{X}$-ray aircraft being operated. The greater the $\mathrm{kV} \mathrm{X}$-ray aircraft give an effect on increasing the dose rate. But looking at the chart trend patterns that occur for 50,70 and $100 \mathrm{kV}$ voltage, it shows the same trend. An increase in $\mathrm{kV}$ does not directly increase the dose rate, but an increase in $\mathrm{kV}$ has more influence on X-ray penetrability (World Health Organization, 2006).

The highest measured dose rate outside the wall occurs at wall $\mathrm{C}(0.020 \mu \mathrm{Sv})$ for on bed examination and wall $\mathrm{B}$ $(0.044 \mu \mathrm{Sv})$ for bucky stand examination. However, for all walls, A, B, C, D, and E the dose rate outside the wall is still below the dose limit value determined by BAPETEN No. 7 of 2009 concerning radiation safety in the use of industrial radiographic equipment (Fakhri \& Wildan, 2015; Vallejo et al., 2019). The T-independent statistical test shows that T-count > T-table (Cember, 1992), with the hypothesis, set stating that according to the criteria Ha is accepted and Ho is rejected, so that significantly $\mathrm{X}$-ray radiation protection at 50,70 and $100 \mathrm{kV}$ meets the safety requirements community and radiation workers.

Putra, I. K., Suryatika, I. B. M., Ratnawati, I. G. A. A., \& Sutapa, G. N. (2019). Radiation protection x-ray in the diagnostic radiology unit kasih ibu kedonganan hospital. International Research Journal of Engineering, IT \& Scientific Research, 5(6), 18-24. https://doi.org/10.21744/irjeis.v5n6.786 


\section{Conclusion}

All walls A, B, C, D, and E can still completely weaken the rate of X-ray radiation dose, so the radiation dose outside the wall is still below the DLV according to BAPETEN No. 7 of 2009. So that the radiation protection in the Radiology unit is Kasih Ibu Kedonganan Hospital is verified as safe for the community and radiation workers.

Conflict of interest statement

The authors declared that they have no competing interests.

Statement of authorship

The authors have a responsibility for the conception and design of the study. The authors have approved the final article.

\section{Acknowledgments}

Thank you to Udayana University for funding the implementation of this research through the Unud DIPA BLU in the fiscal year 2019 by the Letter of Appointment for the Study Program Leading Study No. 2029 / UN14.28.II / LT / 2019. 


\section{References}

Akhadi, M. (2000). Dasar-dasar proteksi radiasi. Jakarta: Rineka Cipta, 41.

Bushong, S. C. (2013). Radiologic science for technologists-E-book: physics, biology, and protection. Elsevier Health Sciences.

Cember, H. (1992). Introduction to Health Physics, Revised and Enlarged.

Fakhri \& Wildan (2015). Measurement of Dose Rate Inside the Triga-2000 Reactor Building Bandung, Department of Physics, Faculty of Mathematics and Natural Sciences, Sebelas Maret University, Surakarta.

Reza R, \& Tekad M. (2013). Design of X-ray Radiology Room Safety at PSTA BATAN Yogyakarta, Proceeding 1st Conference on Safety Engineering and Its Application, Work Safety and Health Engineering Study Program, Surabaya State Polytechnic, Surabaya.

Sutapa, G. N., Yuliara, I. M., \& Ratini, N. N. (2018). Verification of dosage and radiation delivery time breast cancer (Mammae Ca) with ISIS TPS. International Journal of Health Sciences, 2(2), 78-88. https://doi.org/10.29332/ijhs.v2n2.174

Trijaksono T. (2015). Analysis of Environmental Radiology Room Radiation Analysis in Hospitals with the Delphi Program, Journal of Electrical Technology, Mercu Buana University, Nuclear Technology College, National Nuclear Energy Agency, Yogyakarta.

Vallejo, R. S. R., Gámez, M. R., Espinales, A. M. S., \& Pérez, A. V. (2019). Effects of thermal radiation using wood stoves on population health. International Research Journal of Management, IT and Social Sciences, 6(5), 1-8. https://doi.org/10.21744/irjmis.v6n5.656

World Health Organization. (2006). Applying radiation safety standards in diagnostic radiology and interventional procedures using $\mathrm{x}$ rays.

Wulandhari, S. B. Wahyu, \& A. Dwiyanto. (2015), Evaluation of Shield Thickness Calculation Methods in Digital Radiographic Spaces, Youngster Physics Journal, ISSN: 2302 - 7371 Vol. 4, No. 1

Putra, I. K., Suryatika, I. B. M., Ratnawati, I. G. A. A., \& Sutapa, G. N. (2019). Radiation protection x-ray in the diagnostic radiology unit kasih ibu kedonganan hospital. International Research Journal of Engineering, IT \& Scientific Research, 5(6), 18-24. https://doi.org/10.21744/irjeis.v5n6.786 


\section{Biography of Authors}

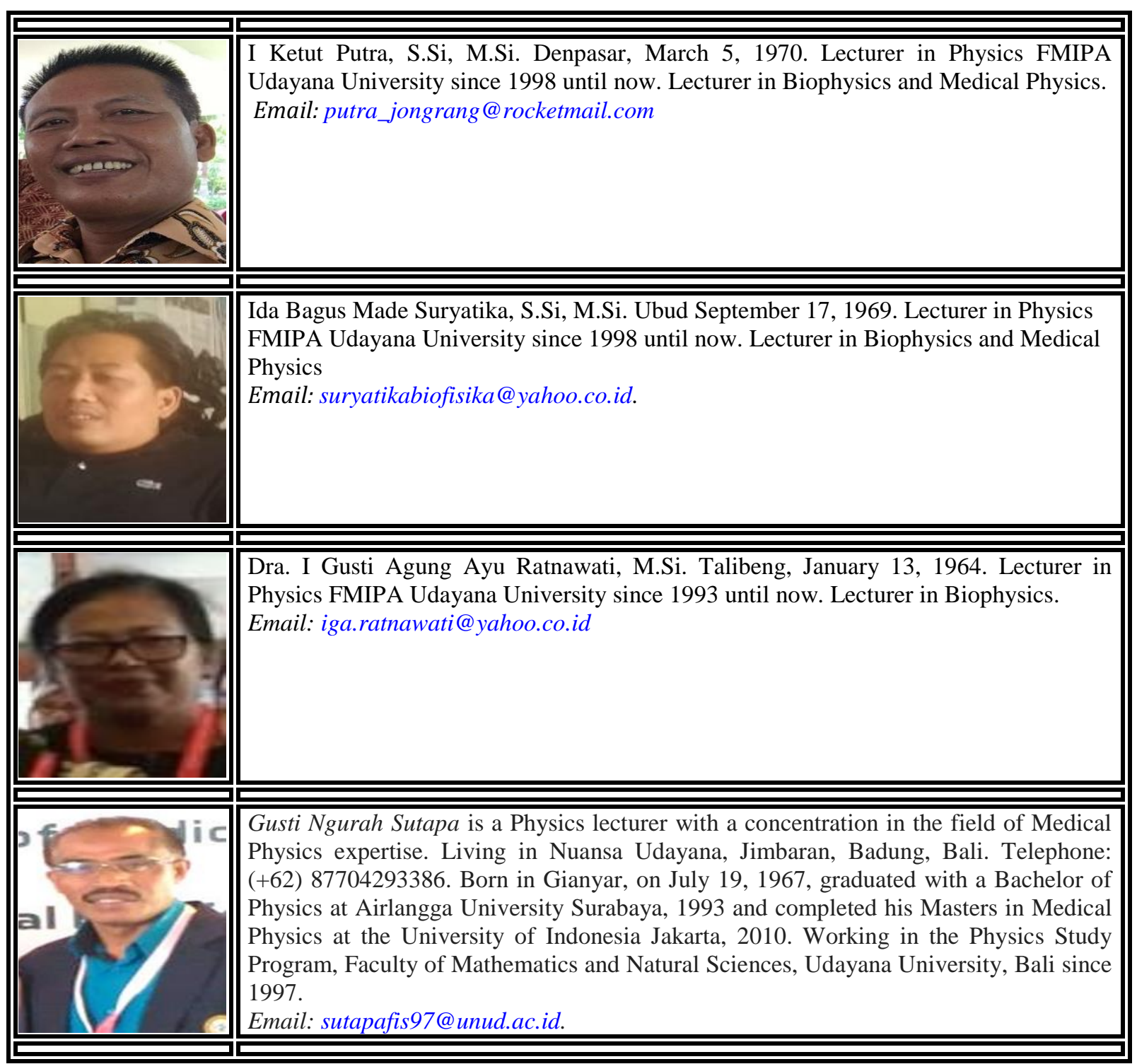

